\title{
Using Google Health Trends to investigate COVID-19 incidence in Africa
}

2 Short title: COVID-19 and Google Health Trends in Africa

3 Alexander Fulk ${ }^{1}$, Daniel Romero-Alvarez ${ }^{1,2,3} *$, Qays Abu-Saymeh ${ }^{1}$, Jarron M. Saint Onge ${ }^{4,5}$, A.

4 Townsend Peterson ${ }^{1,2}$, Folashade B. Agusto ${ }^{1}$

$5 \quad{ }^{1}$ Department of Ecology \& Evolutionary Biology, University of Kansas, Lawrence, Kansas,

$6 \quad$ United States

$7 \quad$ 2Biodiversity Institute, University of Kansas, Lawrence, Kansas, United States

$8 \quad{ }^{3}$ OneHealth Research Group, Facultad de Medicina, Universidad de las Américas, Quito,

9 Ecuador

$10{ }^{4}$ University of Kansas Medical Center, Kansas City, Kansas, United States

$11{ }^{5}$ Department of Sociology, University of Kansas, Lawrence, Kansas, United States

12 *Corresponding author: Daniel Romero-Alvarez. Biodiversity Institute and Department of

13 Ecology \& Evolutionary Biology, 1345 Jayhawk Blvd. Lawrence, Kansas, 66045. United States

14 daromero88@gmail.com

NOTE: This preprint reports new research that has not been certified by peer review and should not be used to guide clinical practice. 
medRxiv preprint doi: https://doi.org/10.1101/2021.03.26.21254369; this version posted March 6, 2022. The copyright holder for this preprint (which was not certified by peer review) is the author/funder, who has granted medRxiv a license to display the preprint in perpetuity.

All rights reserved. No reuse allowed without permission.

\section{ABSTRACT:}

The COVID-19 pandemic has caused over 350 million cases and over five million deaths globally. From these numbers, over 10 million cases and over 200 thousand deaths have occurred on the African continent as of 22 January 2022. Prevention and surveillance remain the cornerstone of interventions to halt the further spread of COVID-19. Google Health Trends (GHT), a free Internet tool, may be valuable to help anticipate outbreaks, identify disease

21 hotspots, or understand the patterns of disease surveillance.

22 We collected COVID-19 case and death incidence for 54 African countries and obtained averages for four, five-month study periods in 2020-2021. Average case and death incidences

24 were calculated during these four time periods to measure disease severity. We used GHT to 25 characterize COVID-19 incidence across Africa, collecting numbers of searches from GHT related to COVID-19 using four terms: 'coronavirus', 'coronavirus symptoms', 'COVID19', and

27 'pandemic'. The terms were related to weekly COVID-19 case incidences for the entire study period via multiple linear regression analysis and weighted linear regression analysis. We also assembled 72 predictors assessing Internet accessibility, demographics, economics, health, and others, for each country, to summarize potential mechanisms linking GHT searches and COVID19 incidence.

COVID-19 burden in Africa increased steadily during the study period as in the rest of the world. Important increases for COVID-19 death incidence were observed for Seychelles and Tunisia over the study period. Our study demonstrated a weak correlation between GHT and COVID-19

35 incidence for most African countries. Several predictors were useful in explaining the pattern of

36 GHT statistics and their relationship to COVID-19 including: log of average weekly cases, log of 
37 cumulative total deaths, and log of fixed total number of broadband subscriptions in a country.

38 Apparently, GHT may best be used for surveillance of diseases that are diagnosed more

39 consistently.

40 GHT-based surveillance for an ongoing epidemic might be useful in specific situations, such as

41 when countries have significant levels of infection with low variability. Overall, GHT-based

42 surveillance showed little applicability in the studied countries. Future studies might assess the

43 algorithm in different epidemic contexts.

44 KEYWORDS: COVID-19, Google Health Trends, Digital Epidemiology, Infodemiology 
medRxiv preprint doi: https://doi.org/10.1101/2021.03.26.21254369; this version posted March 6, 2022. The copyright holder for this preprint (which was not certified by peer review) is the author/funder, who has granted medRxiv a license to display the preprint in perpetuity.

\section{INTRODUCTION}

Coronavirus disease 2019 (COVID-19) is a respiratory disease caused by the severe acute respiratory syndrome coronavirus-2 (SARS-CoV-2) discovered in China in 2019. People infected experience a range of symptoms including headache, fever, difficulty breathing, and loss of taste and smell, or may be completely asymptomatic [1]. Since its discovery, SARS-CoV-2 has spread around the globe, with over 350 million confirmed cases as of 22 January 2022, according to John Hopkins University $[2,3]$. The elderly (>65 years old), as well as those with pre-existing comorbidities, have the highest risk of mortality if infected [4]. COVID-19 spreads via respiratory particles, which allows it to infect others via contaminated aerosols and droplets suspended in the air in closed spaces [5]. Asymptomatic carriers account for a significant amount of secondary transmissions, with some reports showing that $\sim 80 \%$ of infections may occur without symptoms, constituting the source of most secondary COVID-19 cases $[1,6,7]$.

After the large-scale Ebola outbreak in 2015, African leaders were aware that swift and decisive action was needed to avert broad spread of COVID-19 and prevent healthcare system collapse. This awareness led to wide adoption of mitigation and control efforts that circumvented an overwhelming first epidemic wave with a partially structured continental response [8].

61 Regardless, testing in Africa has been limited: about 75\% of COVID-19 diagnoses came from

62 tests conducted in only 10 countries $[5,8]$. The emergence of new of SARS-CoV-2 variants (e.g.,

63 Beta, Delta, Omicron, etc.) has made it difficult to predict wave dynamics across the continent,

64 echoing other regional contexts [9]. Finally, although vaccination campaigns have been

65 promoted as the definitive solution to the pandemic [10], several countries have struggled with

66 vaccine uptake [11]. Africa as a continent has received only about $6 \%$ of the roughly 9 billion 
medRxiv preprint doi: https://doi.org/10.1101/2021.03.26.21254369; this version posted March 6, 2022. The copyright holder for this preprint (which was not certified by peer review) is the author/funder, who has granted medRxiv a license to display the preprint in perpetuity.

All rights reserved. No reuse allowed without permission.

67 doses manufactured so far, even though about $17 \%$ of the world's population lives there [12].

68 Further, uptake has been limited, as only $10 \%$ of Africans have been fully vaccinated [13, 14].

69 Factors determining this context, include disinformation via social media [15]; lack of syringes;

70 lack of health workers to administer vaccines, especially in rural areas [13]; limited government

71 planning; limited testing; and halting efforts at vaccine allocation [16].

Given difficulties in obtaining accurate and timely data on case counts and other

73 epidemiological metrics for COVID-19 worldwide $[17,18]$, the current pandemic represents an

74 opportunity to use digital epidemiology tools to fill gaps in information. Infodemiology is an

75 area of epidemiology that uses digital data to gain insight into disease dynamics $[19,20]$. The

76 digital data used for this method of surveillance vary widely and may or may have not been

77 intended for epidemiological purposes, coming from unexpected sources such as restaurant

78 receipts, Facebook posts, or Google search queries [21, 22, 23].

Google developed two specific algorithms to address infectious diseases, Google Flu

80 Trends (GFT) in 2009 and Google Dengue Trends (GDT) in 2011 [21], which, after inquiries

81 into their usefulness, were shut down in 2015 [24]. Currently, Google maintains two portals by

82 which to harvest search query data: Google Trends (GT) and Google Health Trends (GHT). GT

83 inquiries yield a ranked score from 0 to 100 based on the highest frequency of searches for a

84 term in a particular time period. GHT provides search counts from a relative proportion of a

85 random sample of the overall Google search dataset for any particular term in a selected time

86 interval [25]. Both of these portals have limitations, such as possibly excluding certain groups

87 (e.g., the elderly, rural residents, low income populations), lack of detail on who is searching

88 certain terms, and no insight into the underlying motivations of the searches [26]. 
medRxiv preprint doi: https://doi.org/10.1101/2021.03.26.21254369; this version posted March 6, 2022. The copyright holder for this preprint (which was not certified by peer review) is the author/funder, who has granted medRxiv a license to display the preprint in perpetuity.

All rights reserved. No reuse allowed without permission.

Digital tools have been used in many instances to predict disease incidence $[27,28,29]$ including COVID-19. Kurian et al. (2020) evaluated the applicability of GT in predicting COVID-19 cases in the United States (U.S.) in a state-by-state analysis [30]. They found that

92 certain keywords had a strong correlation with COVID-19 cases, and concluded that GT may be 93 a useful tool for predicting COVID-19 outbreaks. Brodeur et al. (2021) used GT to see how

94 lockdowns affected well-being in the U.S. [31]. Once lockdowns were implemented, well-being 95 likely decreased, as searches for certain terms such as 'stress,' 'suicide,' and 'worry' increased

96 over the lockdown period. Ahmad et al. (2020) used gastrointestinal-related symptom search

97 terms to determine whether GT could predict COVID-19 incidence, and found correlations

98 between the search terms and increases of COVID-19 cases in multiple regions across the U.S.

99 with a four-week lag [32].

Here, we explored whether GHT search query data correlate with COVID-19 incidence at

101 the country level in Africa, as a potential complementary source for more customary forms of

102 COVID-19 surveillance. We decided to use GHT instead of GT given the semi-quantitative 103 nature of the information recovered by GHT. We collected case and death data for 54 African 104 countries, and used four COVID-19-related search terms (see below) for each country. We then 105 assessed whether Internet access, demography, economic information, or health variables, could 106 explain GHT usefulness. Lastly, we calculated a standardized volatility index to illuminate 107 whether variability in the signal of case incidence led to less accurate predictions by GHT.

\section{METHODS}


medRxiv preprint doi: https://doi.org/10.1101/2021.03.26.21254369; this version posted March 6, 2022. The copyright holder for this preprint (which was not certified by peer review) is the author/funder, who has granted medRxiv a license to display the preprint in perpetuity.

All rights reserved. No reuse allowed without permission.

Daily COVID-19 new cases and death counts were obtained for all 54 African countries

111

112

113

114

115

116

117

118

119

120

121

122

124

125

126

127

128

129

130

131

from 2 February 2020 to 25 September 2021. Country-level case data were obtained via the

Johns Hopkins COVID-19 global time series on the pandemic [33]; data were constrained to lab-

confirmed cases only. We explored the progression of average daily COVID-19 case and death incidence per 100,000 people in Africa in four time periods, each roughly five months ( 150 days) long: (a) 2 February 2020 to 30 June, (b) 1 July to 30 November, (c) 1 December to 30 April 2021, and (d) 1 May to 25 September 2021. We then converted daily new cases into weekly new cases for each of the countries to match the weekly GHT data up to 25 September 2021, for a total of 86 observations. We calculated weekly incidence rates by dividing the number of cases per week by the total population per country in millions [34]. Country-level population data were collected from the forecasted midyear 2020 estimates from the U.S. Census Bureau [35].

Google Health Trends data

We downloaded data corresponding to four English terms from the GHT application programming interface (API): ‘coronavirus,' 'coronavirus symptoms,' 'COVID19,' and 'pandemic'. Although the four terms are related conceptually, they have the potential to capture a broad spectrum of information related to the disease $[25,36]$. A simple and specific model is required here to maximize the usefulness of limited GHT data, which is why we have chosen only four terms closely related to the disease to fit the models. We addressed potential language barriers by collecting data for the latter two terms in French and Portuguese. The former two search terms were spelled the same in French and Portuguese, aside from accents, so the English versions of those terms captured a majority of individuals searching those terms in those other 
medRxiv preprint doi: https://doi.org/10.1101/2021.03.26.21254369; this version posted March 6, 2022. The copyright holder for this preprint (which was not certified by peer review) is the author/funder, who has granted medRxiv a license to display the preprint in perpetuity.

All rights reserved. No reuse allowed without permission.

132 languages. We matched the relative search proportions of these words-which is the raw output provided by GHT [25]—with the weekly COVID-19 case incidence for the selected time period.

We used a multiple linear regression model fitted with the four GHT English search terms as predictors of COVID-19 incidence at the country level for each of the 54 African countries being evaluated. We then performed the same analysis, substituting the latter two terms for their equivalents in French or Portuguese if a country had one of these listed as an official or spoken language by Nations Online [37]. The primary outcome measure was the adjusted $R^{2}$ statistic, and we collected whichever adjusted $R^{2}$ value was larger (in absolute value) from the models with all English or English and French/Portuguese terms. If one or more of the four terms

142 chosen did not retrieve search counts from GHT, it was removed from the analysis for that 143 country. At least two terms were included for each region. Multicollinearity may exist in our 144 time series, but it will not affect prediction capabilities or goodness-of-fit [38]. Finally, to 145 address possible autocorrelation and heteroskedasticity issues in our time series, we performed 146 first-order differencing and ran the analyses again with a weighted least squares regression 147 model, giving larger weight to those observations with lower variance. We collected the results 148 from this weighted regression for a more conservative measure. dependent variable and explored whether different categories of predictors might explain the pattern obtained. This analysis was conducted for the adjusted $R^{2}$ statistics collected from the

152 basic fitted regression models and the weighted regression models separately. Predictors for the 153 African countries included Internet access, demographic, economic, and health indicators (Table 
154 1); data were gathered from the World Bank [39]. We explored logarithmic transformations of

155 each of these predictors to determine whether normalization of the indicators led to stronger

156 correlations. Finally, we included as a predictor a standardized volatility index calculated using

157 the standardized normalized case incidence data of each country as follows:

$$
\text { Volatility }=\frac{1}{n-1} \sum_{i=2}^{n}\left|Y_{i}-Y_{i-1}\right|
$$

158 in which $n$ is the total number of observations and $Y$ is the normalized case incidence per

159 country. The average of the absolute difference (i.e., volatility) summarizes the case signal

160 reflecting if it is relatively constant or fluctuates broadly from week to week [25]. Overall, we

161 explored a total of 72 potential explanatory variables (Table 1 and Supplementary Table 1). 
medRxiv preprint doi: https://doi.org/10.1101/2021.03.26.21254369; this version posted March 6, 2022. The copyright holder for this preprint (which was not certified by peer review) is the author/funder, who has granted medRxiv a license to display the preprint in perpetuity.

All rights reserved. No reuse allowed without permission.

Table 1. Predictors explored in the present study. Different categories were selected based on their perceived potential to explain patterns of Google Health Trends and COVID-19 regression models. We also evaluated the log of each predictor, giving for a total of 72 variables. * GDP $=$

166 gross domestic product; HIV = human immunodeficiency virus. Raw values of the variables can

167 be found in Supplementary Table 1.

\begin{tabular}{|c|c|}
\hline Category & Indicator \\
\hline Internet access & $\begin{array}{l}\text { 1. Percentage of population with access to electricity. } \\
\text { 2. Fixed total number of broadband subscriptions in a } \\
\text { country. } \\
\text { 3. Fixed broadband subscriptions per } 100 \text { people. } \\
\text { 4. Fixed total number of telephone subscriptions in a } \\
\text { country. } \\
\text { 5. Fixed telephone subscriptions per } 100 \text { people. } \\
\text { 6. Percentage of individuals using the Internet. } \\
\text { 7. Total number of mobile cellular subscriptions in a } \\
\text { 8. Mobile cellular subscriptions per } 100 \text { people. } \\
\text { 9. Secure Internet servers per } 1 \text { million people. }\end{array}$ \\
\hline Demographics & $\begin{array}{l}\text { 10. Percentage of people } 15 \text { years and above that are } \\
\text { literate. } \\
\text { 11. Percentage of people using at least basic drinking } \\
\text { water services. } \\
\text { 12. Percentage of people using at least basic sanitation } \\
\text { services. } \\
\text { 13. Percentage of people using safely managed drinking } \\
\text { water services. } \\
\text { 14. Percentage of people using safely managed } \\
\text { sanitation services. } \\
\text { 15. Percentage of people with basic handwashing } \\
\text { facilities. } \\
\text { 16. Total population. } \\
\text { 17. Population density as people per square km of land } \\
\text { area. } \\
\text { 18. Total urban population. } \\
\text { 19. Percentage of urban population. }\end{array}$ \\
\hline
\end{tabular}

Economics

20. Percentage of GDP* for current health expenditure. 21. GDP* (current \$ U.S. value). 


22. GDP* per capita (current \$ U.S. value).
23. Average weekly cases over the studied period.
24. Community health workers per 1,000 people.
25. Cumulative total deaths over the study period.
26. Hospital beds per 1,000 people.
27. Total life expectancy (years) at birth.
28. Nurses and midwives per 1,000 people.
29. Physicians per 1,000 people.
30. Percentage of population $15-49$ years with HIV.
31. Prevalence of moderate or severe food insecurity in
the population.
32. Prevalence of severe food insecurity in the
population.
33. Percentage of people at risk of catastrophic
expenditure for surgical care.
34. Percentage of people at risk of impoverishing
expenditure for surgical care.
35. Smoking prevalence for people above 15 years.
36. Volatility score for a country calculated using
weekly incidence.

Variables were analyzed individually using a pair-wise univariate linear regression and collectively in a stepwise regression, in which predictors were added and removed iteratively to

171 obtain a subset of predictors that provided the best model outcome according to the Akaike

172 Information Criterion (AIC). In addition, variables were analyzed using a least absolute

173 shrinkage and selection operator (i.e., LASSO) regression for both untransformed and log-

174 adjusted data to avoid overfitting and produce simpler models. Countries with missing variable

175 information were removed from the univariate regression including that particular variable

$176(38 / 72 ; 53 \%$ of variables had at least one country removed, Supplementary Table 1), and only

177 variables with information for every country were used in the stepwise and LASSO regressions.

178 All analyses were done for both adjusted $R^{2}$ values collected from the basic regression and the 
medRxiv preprint doi: https://doi.org/10.1101/2021.03.26.21254369; this version posted March 6, 2022. The copyright holder for this preprint

(which was not certified by peer review) is the author/funder, who has granted medRxiv a license to display the preprint in perpetuity.

All rights reserved. No reuse allowed without permission.

179 weighted regression. All analyses were performed in R [40]. Data and scripts to replicate the

180 results of this study are available in a GitHub repository accompanying this publication

181 (https://github.com/alxjfulk/GHT-and-COVID19-code).

\section{RESULTS}

184 that dates of first reported COVID-19 cases were centered around March 2020. Egypt (EGY)

185 reported the first case of COVID-19 on the continent on 14 February 2020, 15 days after the

186 World Health Organization (WHO) declared the COVID-19 epidemic an emergency of

187 international concern [41]. Comoros (COM) and Lesotho (LSO) were the last countries to report

188 COVID-19 introductions, with first cases on 30 April and 13 May 2020, respectively (Figure 1). 


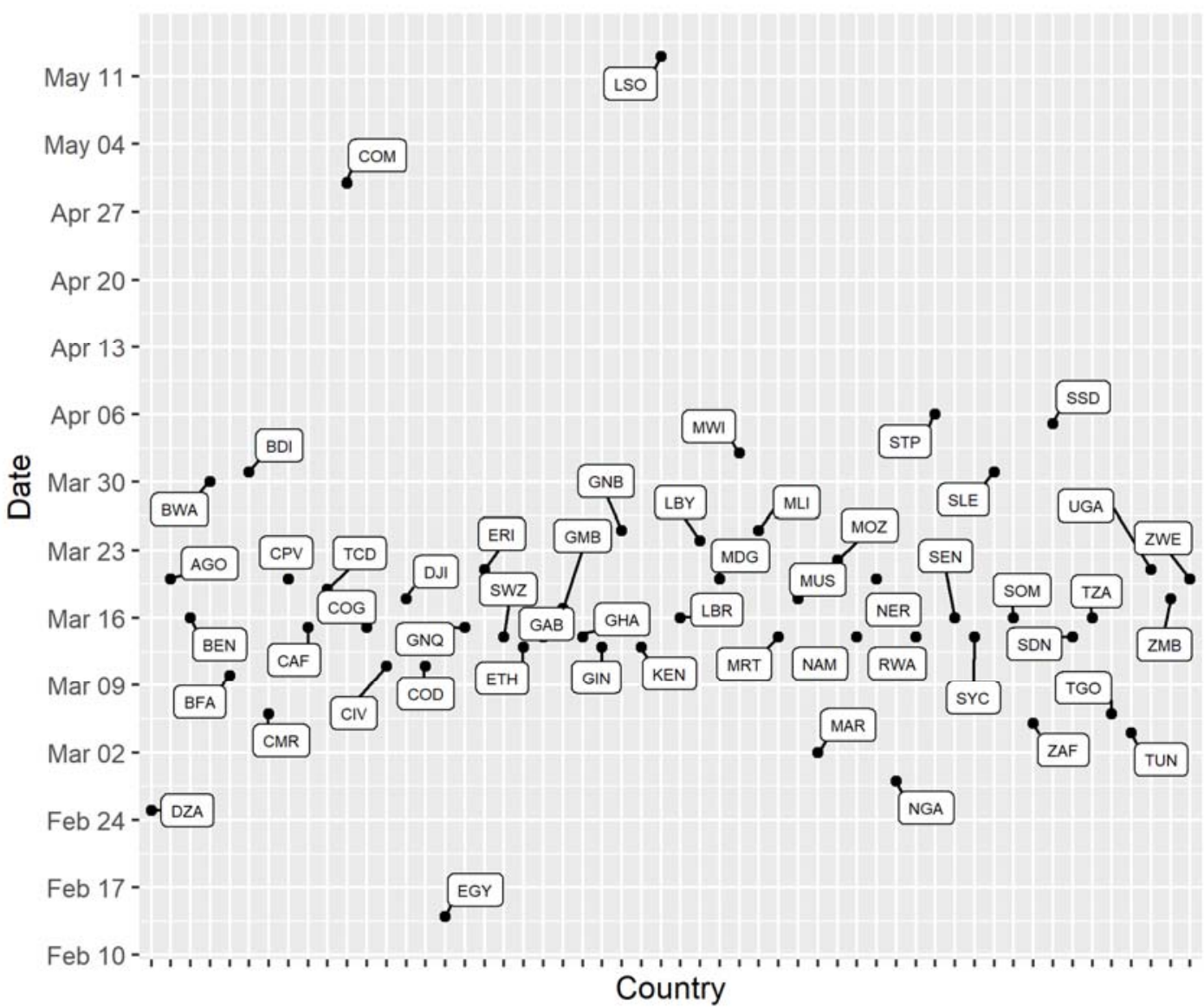

Figure 1. Distribution of the day of the first COVID-19 reported case in 54 African countries. The plot depicts the dates of the first reports of COVID-19 cases in the 54 studied African countries as reported by the Johns Hopkins global time series on the pandemic (CRC, 2020; Dong et al, 2020). The countries in this distribution are designated by their three-letter Alpha-3 codes: DZA: Algeria, AGO: Angola, BEN: Benin, BWA: Botswana, BFA: Burkina Faso, BDI: Burundi, CPV: Cabo Verde, CMR: Cameroon, CAF: Central African Republic, TCD: Chad, COM: Comoros, COD: Democratic Republic of the Congo, COG: Congo, CIV: Côte d'Ivoire, DJI: Djibouti, EGY: Egypt, GNQ: Equatorial Guinea, ERI: Eritrea, SWZ: Eswatini, ETH: Ethiopia, GAB: Gabon, GMB: Gambia, GHA: Ghana, GIN: Guinea, GNB: Guinea-Bissau, KEN: Kenya, LSO: Lesotho, LBR: Liberia, LBY: Libya, MDG: Madagascar, MWI: Malawi, MLI: Mali, MRT: Mauritania, MUS: Mauritius, MAR: Morocco, MOZ: Mozambique, NAM: Namibia, NER: Niger, NGA: Nigeria, RWA: Rwanda, STP: Sao Tome and Principe, SEN: Senegal, SYC: Seychelles, SLE: 

most affected (Fig. 2). For the third and fourth periods, countries across the continent reported

212 increased COVID-19 incidences, with Seychelles (third period = 39.1; fourth period = 109),

213 Tunisia (third period $=12.0$; fourth period $=22.8$ ), Botswana (third period $=10.3$; fourth period $214=37.8$ ), Namibia (third period $=8.55$; fourth period $=20.3$ ), and South Africa (third period $=$ 215 9.28; fourth period $=15.7$ ) ranking top among the countries studied (Fig. 2). Tanzania had an 216 incidence of 0 for the second and third time periods, which will be discussed below.

218 period except for Eritrea, Seychelles, Comoros, Mauritius, Tanzania, and Burundi, although the 219 latter four reported $5.51 \times 10^{-3}, 4.83 \times 10^{-3}, 2.39 \times 10^{-4}$, and $5.62 \times 10^{-5}$ death incidences per 100,000 220 people during the first period, respectively. Further, South Africa (0.219 deaths per 100,000 221 people) and Tunisia (0.179) were the countries reporting the highest death incidence in the 222 second period. For the third period, highest death incidences were again reported in South Africa 223 (0.385) and Tunisia (0.422); for the fourth period, highest incidences were recorded in Tunisia 224 (0.808), Namibia (0.732), and Seychelles (0.584). 
medRxiv preprint doi: https://doi.org/10.1101/2021.03.26.21254369; this version posted March 6, 2022. The copyright holder for this preprint (which was not certified by peer review) is the author/funder, who has granted medRxiv a license to display the preprint in perpetuity.

All rights reserved. No reuse allowed without permission.
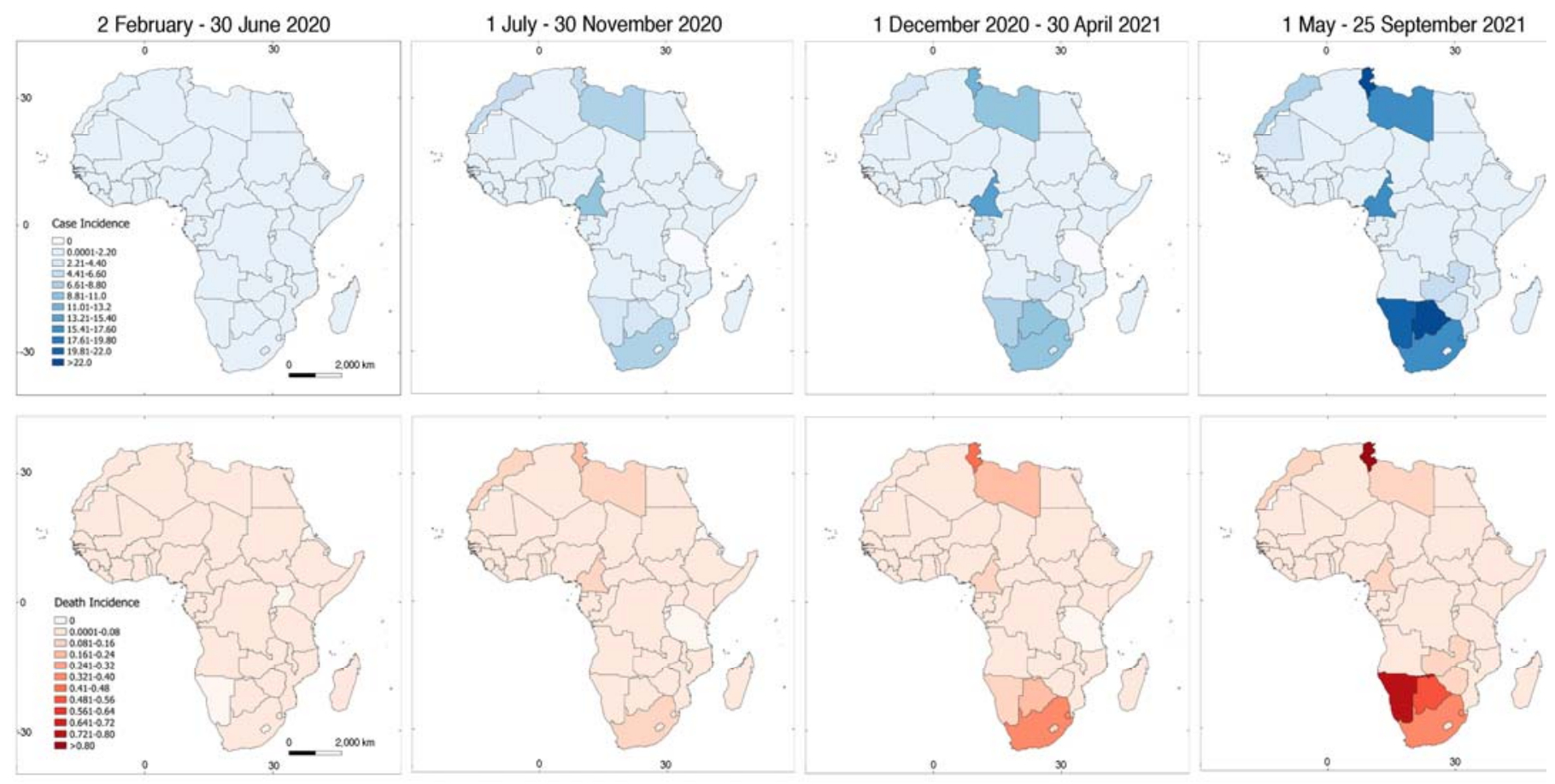

Figure 2. Average case and death incidences of COVID-19 per 100,000 people over four five-month time periods in Africa. Eight plots show average case incidences (upper panels) and average death incidences (bottom panels) over four five-month time periods from 2 February 2020 to 25 September 2021. Scale is the same for all case/death incidence maps and is depicted in the left panels; numbers are individuals affected per 100,000 people.

Few countries had no information for one or two of the chosen English terms (6/54;

$11.1 \%$ ); only 'coronavirus' and 'COVID19' always recovered search query counts. Several countries that had French or Portuguese listed as an official language returned no information for either one or both language-specific terms $(8 / 32 ; 25 \%$, Supplementary Table 2$)$. Overall, the adjusted $R^{2}$ values collected to depict the relationship between GHT search queries and COVID19 weekly incidence were low, never above 0.4 for any of the countries in either the basic regression or the weighted regression (Fig 3). The largest adjusted $R^{2}$ results from the basic regression were for Algeria (0.33), Ethiopia (0.20), and Kenya (0.19; Fig. 4). The countries with 
medRxiv preprint doi: https://doi.org/10.1101/2021.03.26.21254369; this version posted March 6, 2022. The copyright holder for this preprint (which was not certified by peer review) is the author/funder, who has granted medRxiv a license to display the preprint in perpetuity.

All rights reserved. No reuse allowed without permission.

241 the lowest adjusted $R^{2}$ results from the basic regression included Burkina Faso (-0.028), Sierra

242 Leone (-0.030), and Sudan (-0.031; Figs. 3, 4, and Supplementary Table 2). For the weighted

243 regression analysis on the first-order differenced case incidence and GHT data, the countries that

244 returned the largest adjusted $R^{2}$ results were Guinea-Bissau (0.24), Lesotho (0.08), and Niger

245 (0.07, Fig. 3), respectively. The lowest adjusted $R^{2}$ results came from Zimbabwe, Egypt, and

246 Mauritania each with an adjusted $R^{2}$ value of -0.05 (rounded; see Supplementary Figures).

Several of the 72 indicators were able to predict at least in part the pattern of adjusted $R^{2}$ statistics obtained for the 54 African countries. Almost all univariate, linear analyses from the basic regression yielded adjusted $R^{2}$ values of 0.25 or less, except for the log of average weekly cases (0.37), log of cumulative total deaths (0.30), and log of fixed total number of broadband subscriptions in a country (0.26, Supplementary Table 3$)$. The only adjusted $R^{2}$ value greater than 0.25 from the weighted regression analyses came from the number of community health workers per 1,000 people, but that variable only had data for 26 countries. The log of average weekly cases, the log of GDP, and the log of the volatility scores were also statistically significant, though they yielded low adjusted $R^{2}$ values $\left(R^{2}=0.120,0.057\right.$, and 0.080 , respectively; $p=0.0059,0.046$, and 0.022 , respectively). The stepwise regression analysis on the

257 untransformed data showed that a model including percentage of GDP for current health 258 expenditure, life expectancy (years) at birth, mobile cellular subscriptions per 100 people, total 259 population, GDP per capita, percentage of people using the Internet, total urban population, total 260 number of mobile cellular subscriptions in a country, average weekly cases over the studied 261 period, and (notably) volatility score for a country calculated using weekly incidence yielded an 262 adjusted $R^{2}$ of 0.40 . LASSO regression analysis revealed that a model with life expectancy 263 (years) at birth showed an adjusted $R^{2}$ of 0.13 . 
When going further with the analysis using the adjusted $R^{2}$ values collected from the weighted regression model, the volatility score for a country calculated using weekly incidence returned percentage of the population with access to electricity $\left(R^{2}=0.051\right.$, and 0.063 , respectively). Conversely, using logarithmically transformed variables, a stepwise regression

269 model including average weekly cases over the studied period, percentage of GDP for current 270 health expenditure, life expectancy (years) at birth, yielded an adjusted $R^{2}$ value of 0.47 . Using

271 the adjusted $R^{2}$ values collected from the weighted regression analyses, a model including 272 average weekly cases over the time period studied was selected using the stepwise regression.

273 LASSO regression analysis of logarithmic transformed variables indicated that a model

274 including percentage of individuals with access to electricity, life expectancy (years), average

275 weekly cases over the period studied, cumulative deaths, percentage of GDP for current

276 healthcare expenditure, and total population gave the highest adjusted $R^{2}$ of 0.45 . Using the

277 adjusted $R^{2}$ collected from the weighted regression analyses, volatility score for a country

278 calculated using weekly incidence and average weekly cases were returned $\left(R^{2}=0.13\right)$. The

279 results of these models yielded adjusted $R^{2}$ values larger than most of the univariate analyses

280 (Supplementary Table 3); nevertheless, we are cautious in our interpretation of these results [25, $28142,43]$. 


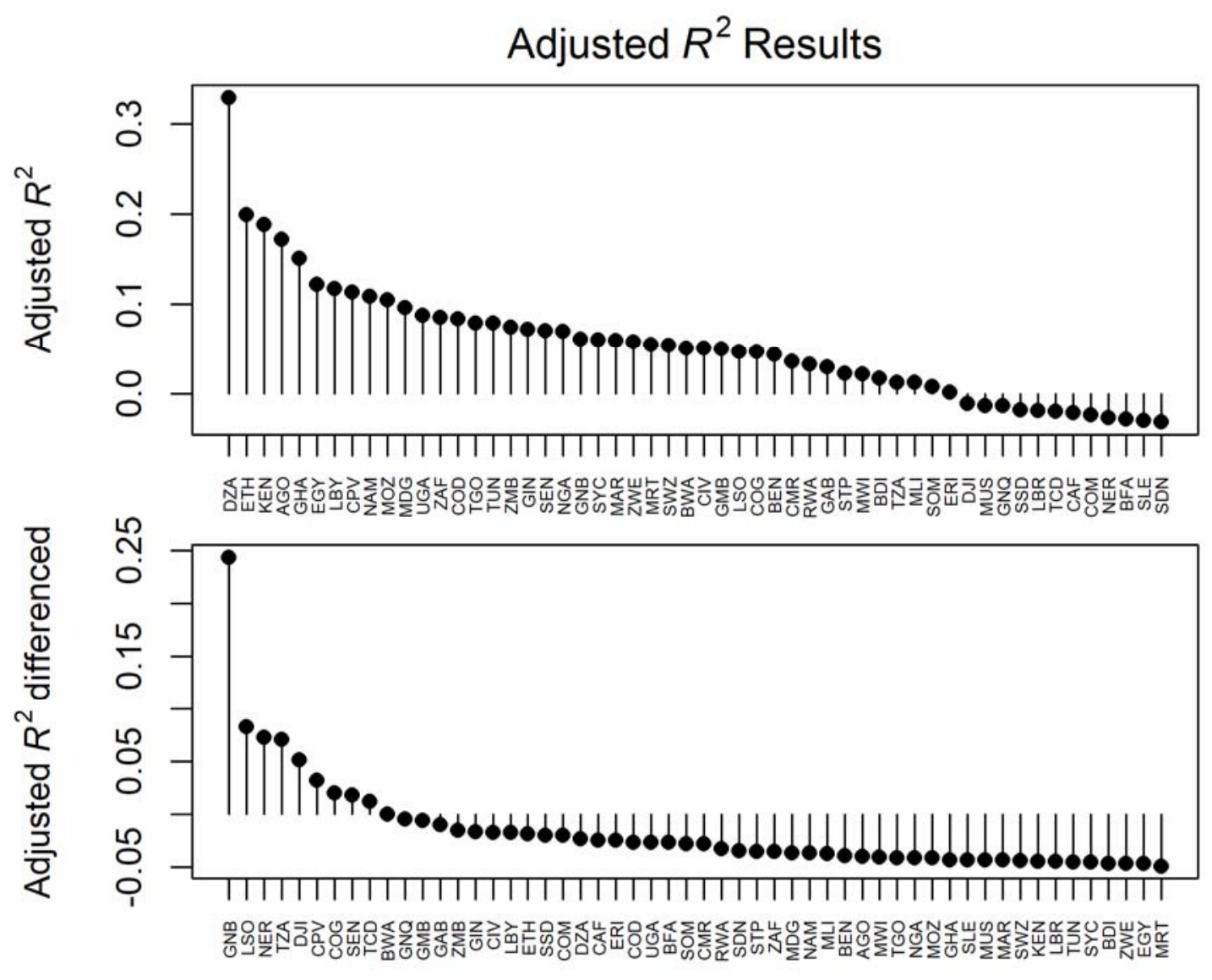

African Countries the basic (upper panel) and the weighted (bottom panel) regression analysis is depicted here to visually represent the countries from the highest to lowest performance. The countries in this figure are designated by their three-letter Alpha-3 codes as in Figure 1. 

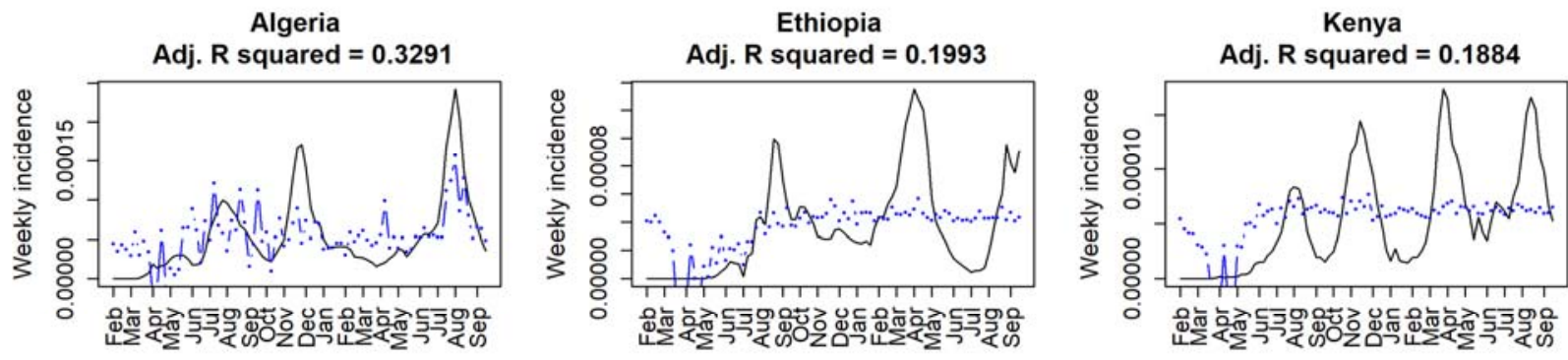

Burkina Faso
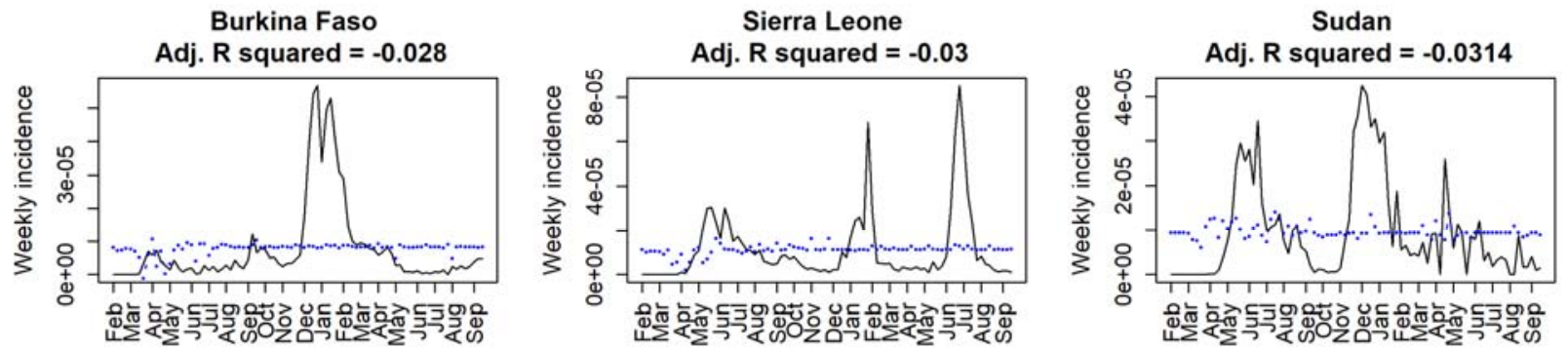

Figure 4. Best and worst performing countries from the basic regression analysis of Google Health Trends (GHT) data. When analyzing whether GHT correlated with case incidence (black line) via a multiple linear regression analysis (blue line), the three best performing countries were Algeria (DZA), Ethiopia (ETH), and Kenya (KEN), respectively (upper panels). The three worst performing countries were Burkina Faso (BFA), Sierra Leone (SLE), and Sudan (SDN), respectively (bottom panels).

\section{DISCUSSION}

Despite successful demonstrations of the GHT algorithm to aid infectious disease surveillance for influenza, dengue, and other diseases [26, 43, 44], our study demonstrates that, in the context of the COVID-19 epidemic, GHT appeared to be difficult to implement as a predictor of COVID-19 incidence and impact. Average weekly cases over the period studied was an important predictor when analyzing possible patterns in the adjusted $R^{2}$ values collected from both the basic regression and weighted regression analyses. The volatility score for a country was also an important predictor of the applicability of GHT, as demonstrated in our univariate, stepwise, and LASSO models (Supplementary Table 3). Finally, indicators related to Internet 
medRxiv preprint doi: https://doi.org/10.1101/2021.03.26.21254369; this version posted March 6, 2022. The copyright holder for this preprint (which was not certified by peer review) is the author/funder, who has granted medRxiv a license to display the preprint in perpetuity.

All rights reserved. No reuse allowed without permission.

access (mobile cellular subscriptions per 100 people, total number of mobile cellular subscriptions in a country, percentage of individuals using the Internet, percentage of individuals with access to electricity), health (life expectancy (years) at birth), demographics (total population, total urban population), and economics (percentage of GDP for current health expenditure, GDP, GDP per capita) were selected heterogeneously with different modeling approaches (Supplementary table 3).

The top three ranking countries based on adjusted $R^{2}$ values in the basic regression (Algeria, Ethiopia, and Kenya) all seemed to have similar COVID-19 incidence signal type (Fig. 4, upper panels). Cases begin at zero, spike, and subsequently drop to a lower, but still significant level of incidence, followed by additional waves, potentially reflecting an exhaustion of susceptible individuals or dynamics of new variants $[45,46]$. Algeria, Ethiopia, and Kenya all had strong responses to initial outbreaks of COVID-19 and invested significantly in preventative measures against COVID-19 such as testing, vaccination, and healthcare [47, 48, 49]. These three countries also ranked within the top 10 when looking at the total number of mobile cellular subscriptions in a country and GDP (Supplementary table 1). On the other hand, Burkina Faso, Sierra Leone, and Sudan are lower-income countries, and have struggled to combat COVID-19 $[50,51,52]$; according to World Bank data, they ranked lower than the top-ranking countries in terms of total number of mobile cellular subscriptions in a country (Supplementary table 1). Furthermore, four out of these six countries had an extremely low percentage of individuals using the Internet $(<20 \%$ as of 2017), which may indicate that the way Internet access is currently measured reflects GHT behavior poorly. Interestingly, the three countries with the worst GHT prediction (Fig. 4, lower panels) showed fewer cases and greater variability in their incidence signal compared to the best-performing countries. The combination of these results 
medRxiv preprint doi: https://doi.org/10.1101/2021.03.26.21254369; this version posted March 6, 2022. The copyright holder for this preprint (which was not certified by peer review) is the author/funder, who has granted medRxiv a license to display the preprint in perpetuity.

All rights reserved. No reuse allowed without permission.

may indicate that some consistent level of infection is required for keeping the interest of communities searching information through Google search engines. This gives GHT a chance to match cases, and it may perform better when a rapid growth of infection coincides with interest in the topic and Internet search volume for disease-specific terms is likely to be high, regardless of the level of penetration of Internet access. Finally, GHT seemed to perform best in those countries that have infrastructure to support accurate case counts.

As in the rest of the world, incidence of both COVID-19 cases and COVID-19 related deaths increased across Africa steadily during the study period. However, in the second and third periods of our study, Tanzania showed zero COVID-19 cases (Fig. 2). Upon closer examination, the country stopped reporting coronavirus cases and deaths in April of 2020, so any patterns that might be observed for Tanzania (0.012) are actually reflecting a lack of data [53]. While COVID-19 numbers are concerning on the continent, Africa has been observed to have a lower disease burden in comparison to other regions of the world [54-57, but see 58]. As of August 2020, Africa had reported approximately 69.2 cases and 1.31 deaths per 100,000 people in nearly seven months since COVID-19 was declared a pandemic; For comparison, the U.S. at that point in time had seen roughly 1500 cases per 100,000 people, and Brazil confirmed roughly 47.0 deaths per 100,000 people $[2,3]$.

Although infodemiology approaches represent the next frontier of infectious disease surveillance $[19,23]$, the present modeling effort demonstrates that search queries from GHT are difficult to correlate with incidence of disease in the context of an emerging epidemic. In contrast with diseases such as influenza or dengue that are studied consistently in a seasonal pattern or are endemic to multiple regions $[25,43,59]$, COVID-19 represented an unprecedented case study that might render Google-based information mining ineffective for several reasons: (a) partial or 
medRxiv preprint doi: https://doi.org/10.1101/2021.03.26.21254369; this version posted March 6, 2022. The copyright holder for this preprint (which was not certified by peer review) is the author/funder, who has granted medRxiv a license to display the preprint in perpetuity.

All rights reserved. No reuse allowed without permission.

353 incomplete COVID-19 case detection and reporting [8, 60], (b) media-induced search behavior

354 [61], or even (c) information fatigue [36]. Thus, we encourage caution regarding interpretation of

355 COVID-19 modeling experiments based on Google search engines. For example, Ahmad et al.

356 (2020) found a correlation between gastrointestinal search terms obtained through GT and

357 COVID-19 cases and suggested that Internet searches may be useful in predicting COVID-19

358 cases using a four-week lag in the U.S. [32]. This correlation, however, might be an artifact since

359 none of the gastrointestinal terms is specific to COVID-19, and the only COVID-19 specific

360 term - 'ageusia' - increased during the time that the pandemic was declared (i.e., 11 March) and

361 decreased while cases started to increase (Figure 1 in [32]). The U.S. showed an increase in case

362 numbers driven by increasing test capacity, thus, these case numbers were reflecting disease

363 incidence inaccurately [62]. Thus, although our findings are based on the GHT algorithm, we are

364 cautious about interpreting our results and those of others in characterizing COVID-19 via

365 Google search engines. Similar to our findings, Asseo et al. (2020) found correlations between

366 GT search queries related to smell and taste at the beginning of the pandemic in Italy and the

367 U.S., which faded in succeeding epidemiological weeks [36]. More importantly, Asseo et al.

368 (2020) also showed how correlation patterns fall apart when analyzing Google search queries

369 and COVID-19 incidence in nonconsecutive weeks (e.g. 11-17 March vs. 1-7 April 2020 in

$370[36])$.

Some limitations of the present research are as follows. Because of the timeframe of the

372 study and the availability of GHT data as weekly counts, we had to convert daily cases to weekly

373 cases, limiting our analysis to only 86 observations, decreasing the statistical power of our

374 approach. Moreover, the four terms related with COVID-19 that were selected might not be as

375 popular in the region as expected. Language might be an important although permeable barrier 
medRxiv preprint doi: https://doi.org/10.1101/2021.03.26.21254369; this version posted March 6, 2022. The copyright holder for this preprint (which was not certified by peer review) is the author/funder, who has granted medRxiv a license to display the preprint in perpetuity.

All rights reserved. No reuse allowed without permission.

376

377

378

379

380

381

382

$[25,27]$. Still, in the present study the addition of French and Portuguese translations of search terms did not yield significantly higher adjusted $R^{2}$ values (Supplementary Table 2). Finally, we lacked complete data for some of the predictors (e.g., prevalence of severe food insecurity in the population; Supplementary Table 3) which halts interpretation of several of the indicators used; however, those that were available for all the countries proved useful here as in other research studies (e.g., total population, signal volatility, disease incidence, etc) [25, 43].

\section{CONCLUSIONS}

Surveillance for an ongoing epidemic via GHT might be useful in specific situations in which accurate case counts can be retrieved and there is sustained level of disease incidence. Google instruments to recover population search counts—GT and GHT — are potentially powerful digital epidemiology tools that can lead to greater insight into disease dynamics, and should be studied and implemented depending on the particular context of an outbreak [25, 30, 63-66]. Future directions to examine GHT on COVID-19 research include expansion of the analysis to a larger dataset both in time and space. Other refinements can be implemented, combining other forms of digital data (e.g., Twitter, Wikipedia) to determine if addition of more information improves the predictive power of the model.

\section{ACKNOWLEDGMENTS}

DRA thanks the writing-original-group (WOG) for support during the development of this paper.

\section{FUNDING}

Our research is supported by the National Science Foundation with the grant number DMS 2028297.

\section{SUPPLEMENTARY MATERIAL:}


398 Supplementary Table 1. Raw data for the predictors used to explore patterns of Google Health

399 Trends search queries and COVID-19 incidence in 54 African countries.

400 Supplementary Table 2. Date of the first COVID-19 case reported in Africa. Results of 401 multiple linear regression analysis performed between COVID-19 incidence and Google Health 402 Trends search queries from four selected terms.

403 Supplementary Table 3. Univariate and multivariate linear regression analysis to explore 404 associations between adjusted $R^{2}$ of Google Health Trends search queries and COVID-19 405 incidence in 54 African countries.

406 Supplementary Figures. Plots depicting the best and worst performing countries in the 407 weighted regression analysis and plots depicting the multiple linear regression models between 408 COVID-19 case counts and Google Health Trends search queries for the 54 African countries 409 studied in the present manuscript. 


\section{REFERENCES}

1. CDC. Coronavirus Disease 2019 (COVID-19). 2020a. Available from: https://www.cdc.gov/coronavirus/2019-ncov/need-extra-precautions/older-adults.html (accessed 3 November 2020).

2. Johns Hopkins Coronavirus Resource Center (CRC). COVID-19 Dashboard. 2020. Available from: https://coronavirus.jhu.edu/ (accessed 7 December 2021).

3. Dong E, Du H, Gardner L. An interactive web-based dashboard to track COVID-19 in real time. Lancet Infect Dis 2020;20:533-34. associated with COVID-19-related death using OpenSAFELY. Nature 2020;584:430-6. https://www.who.int/news-room/q-a-detail/coronavirus-disease-covid-19-how-is-ittransmitted (accessed 7 December 2020). infection facilitates the rapid dissemination of novel coronavirus (SARS-CoV-2). Science 2020;368:489-93.

7. Zhang R, Li Y, Zhang AL, Wang Y, Molina MJ. Identifying airborne transmission as the dominant route for the spread of COVID-19. Proc Natl Acad Sci 2020;117:14857-63. 19 in Africa: the spread and response. Nat Med 2020;26:999-1003. 
medRxiv preprint doi: https://doi.org/10.1101/2021.03.26.21254369; this version posted March 6, 2022. The copyright holder for this preprint (which was not certified by peer review) is the author/funder, who has granted medRxiv a license to display the preprint in perpetuity.

All rights reserved. No reuse allowed without permission.

10. Mayo Clinic. Herd Immunity and COVID-19 (coronavirus): What you need to know. 2021. Available from: https://www.mayoclinic.org/diseases-conditions/coronavirus/indepth/herd-immunity-and-coronavirus/art-20486808 (accessed 2 February 2022).

11. Beaubien J. For the 36 countries with the lowest vaccination rates, supply isn't the only issue. NPR 2022. Available from: https://www.npr.org/sections/goatsandsoda/2022/01/14/1072188527/for-the-36countries-with-the-lowest-vaccination-rates-supply-isnt-the-only-issu (accessed 2 February 2022).

12. Sidibé M. Vaccine Inequity: Ensuring Africa is not left out. Brookings 2022. Available from: https://www.brookings.edu/blog/africa-in-focus/2022/01/24/vaccine-inequityensuring-africa-is-not-left-out/ (accessed 29 January 2022).

13. Adepoju P. As COVID-19 vaccines arrive in Africa, Omicron is reducing supply and increasing demand. Nature Medicine 2021.

14. Africa CDC. COVID-19 Vaccination. 2022. Available from: https://africacdc.org/covid-

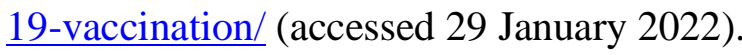

15. Md SI, Tonmoy S, Sazzad HK, Abu-Hena MK, S. M. MH, Alamgir K, et al. COVID-19Related infodemic and its impact on public health: a global social media analysis. American Society of Tropical Medicine and Hygiene 2020;103:1621-29.

16. WHO. Key lessons from Africa's COVID-19 vaccine rollout. 2021. Available from: https://www.afro.who.int/news/key-lessons-africas-covid-19-vaccine-rollout (accessed 29 January 2022). 
17. Fairchild G, Tasseff B, Khalsa H, Generous N, Daughton AR, Velappan N, et al. Epidemiological data challenges: planning for a more robust future through data standards. Front Public Health 2018;6:336.

18. Wu SL, Mertens AN, Crider YS, Nguyen A, Pokpongkiat NN, Djajadi S, et al. 2020;11:4507.

19. Salathé M. Digital epidemiology: what is it, and where is it going? Life Sci Soc Policy $2018 ; 14: 1-5$.

20. Vlajinac H. Epidemiology, aims and scope. In: Kirch W, editor. Encyclopedia of public health. Dordrecht: Springer Netherlands; 2008, p. 350-2. trends: an update. Int. Soc. Neglected Trop. Dis. 2013. Available from: https://storage.googleapis.com/pub-tools-public-publication-data/pdf/41763.pdf (accessed 23 March 2021).

22. Nsoesie EO, Buckeridge DL, Brownstein JS. Guess who’s not coming to dinner? Evaluating online restaurant reservations for disease surveillance. J Med Internet Res 2014;16:e22.

\section{Pollett S, Althouse BM, Forshey B, Rutherford GW, Jarman RG. Internet-based} biosurveillance methods for vector-borne diseases: Are they novel public health tools or just novelties? PLoS Negl Trop Dis 2017a;11:e0005871.

24. Lazer D, Kennedy R, King G, Vespignani A. The parable of Google Flu: traps in big data analysis. Science 2014;343:1203-5. 
medRxiv preprint doi: https://doi.org/10.1101/2021.03.26.21254369; this version posted March 6, 2022. The copyright holder for this preprint (which was not certified by peer review) is the author/funder, who has granted medRxiv a license to display the preprint in perpetuity.

25. Romero-Alvarez D, Parikh N, Osthus D, Martinez K, Generous N, del Valle S, et al. Google Health Trends performance reflecting dengue incidence for the Brazilian states. BMC Infect Dis 2020;20:252.

26. Arora VS, McKee M, Stuckler D. Google Trends: opportunities and limitations in health and health policy research. Health Policy 2019;123:338-41.

27. Althouse BM, Ng YY, Cummings DAT. Prediction of dengue incidence using search query surveillance. PLoS Negl Trop Dis 2011;5:e1258.

28. Xu C, Bai Y, Yang H, Cao X, Jia P, Wang Y. Detecting lung cancer trends by leveraging real-world and Internet-based data: infodemiology study. J Med Internet Res. 2020;22:e1684.

29. Zhang Q, Perra N, Perrotta D, Tizzoni M, Paolotti D, Vespignani A. Forecasting seasonal influenza fusing digital indicators and a mechanistic disease model. Proc. 26th Int. Conf. World Wide Web 2017; 311-19.

30. Kurian SJ, Bhatti A ur R, Alvi MA, Ting HH, Storlie C, Wilson PM, et al. Correlations between COVID-19 cases and Google Trends data in the United States: a state-by-state analysis. Mayo Clin Proc 2020;95:2370-81.

31. Brodeur A, Clark A, Fleche S, Powdthavee N. COVID-19, lockdowns and well-being: evidence from Google Trends. J Public Econ 2021:193;104346.

32. Ahmad I, Flanagan R, Staller K. Increased Internet search interest for GI symptoms may predict COVID-19 cases in US hotspots. Clin Gastroenterol Hepatol 2020;18:2833-34.

33. Center for Systems Science and Engineering (CSSE). COVID-19 data repository. Johns Hopkins University. 2020. Available from: https://github.com/CSSEGISandData/COVID-19 (accessed 22 January 2022). 
medRxiv preprint doi: https://doi.org/10.1101/2021.03.26.21254369; this version posted March 6, 2022. The copyright holder for this preprint (which was not certified by peer review) is the author/funder, who has granted medRxiv a license to display the preprint in perpetuity.

All rights reserved. No reuse allowed without permission.

34. Vandenbroucke J, Pearce N. Incidence rates in dynamic populations. Int J Epidemiol 2012;41:1472-79.

35. United States Census Bureau. International Data Base (IDB). 2020. Available from: https://www.census.gov/data-tools/demo/idb/ /country?YR_ANIM=2020\&FIPS_SINGLE=AG (accessed 15 December 2020).

36. Asseo K, Fierro F, Slavutsky Y, Frasnelli J, Niv MY. Tracking COVID-19 using taste and smell loss Google searches is not a reliable strategy. Sci Rep 2020;10:20527.

37. Nations Online. Official and spoken languages of African countries. Available from: https://www.nationsonline.org/oneworld/african_languages.htm (accessed 22 January 2022).

38. Mundfrom D, Smith M, Kay L, The effect of multicollinearity on prediction in regression models. GLMJ 2018;44:24-28.

39. The World Bank. Indicators. 2020. Available from: https://data.worldbank.org/indicator (accessed 7 December 2020).

40. R Core Team. R: A language and environment for statistical computing. R Foundation for Statistical Computing,Vienna, Austria. 2017. Available from: https://www.Rproject.org/ (accessed 7 December 2020).

41. WHO. COVID-19 Public Health Emergency of International Concern (PHEIC) Global research and innovation forum. 2020. Available from: https://www.who.int/publications/m/item/covid-19-public-health-emergency-ofinternational-concern-(pheic)-global-research-and-innovation-forum (accessed 5 January 2021). 
42. James G, Witten D, Hastie T, Tibshirani R. An introduction to statistical learning with applications in R. 1st ed. New York: Springer; 2013.

43. Gluskin R, Johansson M, Santillana M, Brownstein J. Evaluation of Internet-based dengue query data: Google Dengue Trends 2014. PLoS Negl Trop Dis 2011;8:e2713.

44. Messina JP, Brady OJ, Golding N, Kraemer MUG, Wint GRW, Ray SE, et al. The current and future global distribution and population at risk of dengue. Nat Microbiol $2019 ; 4: 1508-15$.

45. Kastalskiy IA, Pankratova EV, Mirkes EM, Kazantsev VB, Gorban AN. Social stress drives the multi-wave dynamics of COVID-19 outbreaks. Sci Reports 2021;11;22497.

46. Kupferschmidt K. Viral mutations may cause another 'very, very bad' COVID-19 wave, scientists warn. Science Insider 2021. Available from: https://www.science.org/content/article/viral-mutations-may-cause-another-very-verybad-covid-19-wave-scientists-warn (accessed 29 January 2022).

47. Klouche-Djedid SN, Shah J, Khodor M, Kacimi SEO, Islam SM, Aiash H. Algeria's response to COVID-19: an ongoing journey. Lancet 2021;9:449.

48. Tesfay F. How conflict has made COVID-19 a neglected epidemic in Ethiopia. The Conversation 2021. Available from: https://theconversation.com/how-conflict-has-madecovid-19-a-neglected-epidemic-in-ethiopia-167499 (accessed 29 January 2022).

49. Wangari EN, Gichuki P, Abuor AA, Wambui J, Okeyo SO, Oyatsi HTN, et al. Kenya's response to the COVID-19 pandemic: a balance between minimising morbidity and adverse economic impact. AAS Open Res. 2021;4:3. 
medRxiv preprint doi: https://doi.org/10.1101/2021.03.26.21254369; this version posted March 6, 2022. The copyright holder for this preprint (which was not certified by peer review) is the author/funder, who has granted medRxiv a license to display the preprint in perpetuity.

All rights reserved. No reuse allowed without permission.

50. Traoré IT, Ouedraogo S, Kania D, Kaboré FN, Konaté B, Médah R, et al. COVID-19 epidemiological, sociological and anthropological investigation: study protocol for a multidisciplinary mixed methods research in Burkina Faso. BMC Infect Dis 2021;21:896.

51. Parmley LE, Hartsough K, Eleeza O, Bertin A, Sesay B, et al. COVID-19 preparedness at health facilities and community service points serving people living with HIV in Sierra Leone. PLoS ONE 2021;16(4):e0250236.

52. Mukhtar MM, Khogali M. The accelerating COVID-19 epidemic in Sudan. Nat Immunol 2021;22:797-98.

53. Makoni M. Tanzania refuses COVID-19 vaccines. Lancet 2021;397:566.

54. Soy A. Coronavirus in Africa: five reasons why Covid-19 has been less deadly than elsewhere. BBC News 2020a. Available from: https://www.bbc.com/news/world-africa$\underline{54418613}$ (accessed 22 March 2021).

55. Mwai P. Coronavirus: What's happening to the numbers in Africa? BBC News 2020b. Available from: https://www.bbc.com/news/world-africa53181555?intlink_from_url=https://www.bbc.com/news/world\&link_location=livereporting-story (accessed 7 December 2020).

56. European Centers Disease Prevention and Control. COVID-19 situation update worldwide, as of 14 December 2020. 2020. Available from: https://www.ecdc.europa.eu/en/geographical-distribution-2019-ncov-cases (accessed 15 December 2020). 57. Maeda JM, Nkengasong JN. The puzzle of the COVID-19 pandemic in Africa. Science 2021;371:27-8. 
medRxiv preprint doi: https://doi.org/10.1101/2021.03.26.21254369; this version posted March 6, 2022. The copyright holder for this preprint (which was not certified by peer review) is the author/funder, who has granted medRxiv a license to display the preprint in perpetuity.

58. Mwananyanda L, Gill CJ, MacLeod W, Kwenda G, Pieciak R, Mupila Z, et al. Covid-19 deaths in Africa: prospective systematic postmortem surveillance study. BMJ 2021;372:n334.

59. Pollett S, Boscardin WJ, Azziz-Baumgartner E, Tinoco YO, Soto G, Romero C, et al. Evaluating Google Flu Trends in Latin America: important lessons for the next phase of digital disease detection. Clin Infect Dis 2017b;64:34-41.

60. Schneider EC. Failing the test—-the tragic data gap undermining the US pandemic response. N Engl J Med 2020;383:299-302.

61. Southwell BG, Dolina S, Jimenez-Magdaleno K, Squiers LB, Kelly BJ. Zika virusrelated news coverage and online behavior, United States, Guatemala, and Brazil. Emerg Infect Dis 2016;22:1320-1.

62. Stokes EK, Zambrano LD, Anderson KN, Marder EP, Raz KM, Felix SEB, et al. Coronavirus disease 2019 case surveillance-United States, January 22-May 30, 2020. Morb Mortal Wkly Rep 2020;69:759-65.

63. Nuti SV, Wayda B, Ranasinghe I, Wang S, Dreyer RP, Chen SI, et al. The use of Google Trends in health care research: a systematic review. PLoS ONE 2014;9 e109583.

64. Pelat C, Turbelin C, Bar-Hen A, Flahault A, Valleron A-J. More diseases tracked by using Google Trends. Emerg Infect Dis 2009;15:1327-8.

65. Samaras L, García-Barriocanal E, Sicilia MA. Comparing social media and Google to detect and predict severe epidemics. Sci Rep 2020;10:4747.

66. Valdivia A, Monge-Corella S. Diseases tracked by using Google Trends, Spain. Emerg Infect Dis 2010;16:168. 